\title{
Analisis Rasio Keuangan Koperasi KPRI Hikmah
}

\author{
Yelsha Dwi Pasca
}

yelshadwipasca@gmail.com

\section{Artikel info Artikel history: Diterima 27 Mei 2021 Diterima dalam bentuk revisi Diterima dalam bentuk revisi}

\section{Keywords:}

fnancial ratios, trend and common size

\begin{abstract}
:
This study aims to determine the financial conditions and developments of KPRI Hikmah in 2017 - 2019 by using the ratio of liquidity, solvency, profitability and activity. The type of research conducted in the form of a case study on the KPRI Hikmah Majalengka Cooperative. Data collection techniques used are documentation and interviews. The data analysis technique used is calculating the ratios of liquidity, solvency, profitability and activity, analyzing using trends and common sizes. Based on the financial data analysis of the KPRI Hikmah cooperative, it was concluded that the level of liquidity measured using the current ratio in 2017 - 2019 was categorized as very good. The level of solvency measured using total debt to equity and total debt to total assets ratio in 2017 - 2019 is categorized as good. The level of profitability measured using net profit margins in 2017 - 2019 is categorized as very good. Return on assets and profitability of own capital are categorized as quite good. The level of activity as measured by asset turnover is categorized as good. The results of trend analysis on the current ratio, total debt to equity ratio, total debt to total assets ratio and net profit margin in 2017 - 2019 have increased performance, while return on assets, own capital earnings and asset turnover have decreased. The results of the common size analysis on the balance sheet and the remaining operating results tend to experience a decline in their financial development. The liquidity ratio has excellent financial conditions and developments, so cooperatives need to maintain and increase their total assets.
\end{abstract}

\begin{abstract}
Abstrak:
Penelitian ini bertujuan untuk mengetahui kondisi dan perkembangan keuangan KPRI Hikmah tahun 2017 - 2019 dengan menggunakan rasio likuiditas, solvabilitas, rentabilitas dan aktivitas. Jenis penelitian yang dilakukan berupa studi kasus pada Koperasi KPRI Hikmah Majalengka. Teknik pengumpulan data yang digunakan adalah dokumentasi dan wawancara. Teknik analisis data yang digunakan yaitu menghitung rasiorasio likuiditas, solvabilitas, rentabilitas dakn aktivitas, menganalisis dengan menggunakan trend dan common size. Berdasarkan hasil analisis data keuangan koperasi KPRI Hikmah diperoleh kesimpulan bahwa tingkat likuiditas yang diukur menggunakan current ratio pada tahun 2017 - 2019 dikategorikan sangat baik. Tingkat solvabilitas yang diukur menggunakan total debt to equity dan total debt to total assets ratio pada tahun 2017 2019 dikategorikan baik. Tingkat rentabilitas diukur menggunakan net profit margin pada tahun 2017 - 2019 dikategorikan sangat baik. Return on assets dan rentabilitas modal sendiri dikategorikan cukup baik. Tingkat aktivitas yang diukur menggunakan perputaran aktiva dikategorikan baik. Hasil analisis trend pada current ratio, total debt to equity ratio, total debt to total asset ratio dan net profit margin pada tahun 2017 - 2019 mengalami peningkatan kinerja, sedangkan return on assets, rentabilitas modal sendiri dan perputaran aktiva mengalami penurunan. Hasil analisis common size
\end{abstract}


Kata Kunci:

rasio keuangan; trend dan common size. pada laporan neraca dan sisa hasil usaha cenderung mengalami penurunan dalam perkembangan keuangannya. Rasio likuiditas memiliki kondisi dan perkembangan keuangan yang sangat baik sehingga koperasi perlu mempertahankan dan meningkatkan total aktivanya.

\section{Coresponden author: Yelsha Dwi Pasca}

Email: yelshadwipasca@gmail.com artikel dengan akses terbuka dibawah lisensi

CC BY SA 2021

\section{Pendahuluan}

Kondisi ekonomi yang selalu mengalami perubahan telah mempengaruhi kegiatan dan kinerja perusahaan, baik perusahaan kecil maupun perusahaan besar sehingga banyak perusahaan yang bangkrut. Kebangkrutan suatu perusahaan dapat dilihat dan diukur melalui laporan keuangannya. Agar informasi Laporan keuangan yang tersaji menjadi lebih bermanfaat dalam pengambilan keputusan, maka data keuangan harus dikonversi menjadi informasi yang berguna dalam pengambilan keputusan ekonomis. Untuk membuktikan bahwa laporan keuangan bermanfaat maka perlu dilakukan penelitian (Fahmi, 2013).

Laporan keuangan yang diterbitkan oleh perusahaan merupakan salah satu sumber informasi mengenai posisi keuangan perusahaan, kinerja serta perubahan posisi keuangan perusahaan, yang sangat berguna untuk mendukung pengambilan keputusan yang tepat, agar informasi yang tersaji menjadi lebih bermanfaat dalam pengambilan keputusan, data keuangan harus dikonversi menjadi informasi yang berguna dalam pengambilan keputusan ekonomis. Hal ini ditempuh dengan cara melakukan analisis laporan keuangan. Model yang sering dilakukan dalam melakukan analisis tersebut adalah dalam bentuk rasio-rasio keuangan (Mawardi, 2004).

Laporan keuangan koperasi meliputi neraca, laporan Sisa Hasil Usaha (SHU), laporan arus kas dan catatan atas laporan keuangan. Salah satu alat ukur laporan keuangan yaitu rasio keuangan. Rasio menggambarkan suatu hubungan atau pertimbangan antara suatu jumlah tertentu dengan jumlah yang lain dengan menggunakan alat analisis berupa rasio keuangan yang dapatmenjelaskan dan memberikan gambaran tentang baik dan buruknya keadaan atau posisi keuangan dari suatu period eke periode berikutnya. Rasio keuangan yang digunakan untuk menganalisis terdiri dari rasio likuiditas, rasio solvabilitas, rasio rentabilitas, dan rasio aktivitas. Perkembangan keuangan koperasi dinilai menggunakan trend dan common size. Analisis trend digunakan untuk melihat perkembangan koperasi melalui grafik yang naik turun dan analisis common size berupa penyederhanaan angka-angka pada laporan keuangan dalam bentuk persen (Toto, 2011).

Koperasi adalah suatu perkumpulan yang didirikan oleh orang-orang yang memiliki kemampuan ekonomi terbatas yang bertujuan untuk memperjuangkan peningkatan kesejahteraan ekonomi mereka. Prinsippengelolaan koperasi merupakan penjabaran lebih lanjut dari asa kekeluargaan yang dianutnya. Prinsip-prinsip koperasi ini biasanya mengatur baik hubungan antar koperasi dengan para anggotanya, hubungan antar sesama anggota koperasi, pola kepengurusan organisasi koperasi, serta mengenai tujuan yang ingin dicapai oleh koperasi sebagai lembaga ekonomi yang berasas kekeluargaan. Selain itu, prinsip 
koperasi biasanya juga mengatur pola kepengelolaan usaha koperasi.

Laporan keuangan merupakanringkasan dari transaksi-transaksi keuangan yang terjadi selama satu tahun buku bersangkutan menggambarkan kemajuan perusahaan dan disusun secara periodik. Ada beberapa pengertian laporan keuangan, yaitu laporan keuangan meliputi bagian dari proses laporan keuangan. Laporan keuangan yang lengkap biasanya meliputi neraca, laporan laba rugi, laporan perubahan ekuitas, laporan perubahan posisi keuangan (yang dapat disajikan dalam berbagai cara misalnya, sebagai laporan arus kas/laporan arus dana), catatan dan laporan lain serta materi penjelasan yang merupakan bagian integraldari laporan keuangan (Ikatan Akuntan Indonesia, 2009).

Secara umum ada lima jenis laporan keuangan yang biasa disusun, (Kasmir, 2012) yaitu:

\section{Balance Sheet (Neraca)}

laporan yang menunjukkan posisi keuangan perusahaan pada tanggatertentu. Arti dari posisi keuangan dimaksudkan adalah posisi jumlah dan jenis aktiva (harta) dan passiva (kewajiban dan ekuitas) suatu perusahaan.

2. Income Statement (Laporan Laba Rugi )

Laporan keuangan (laporan laba rugi) yang menggambarkan hasil usaha perusahaan dalam suatu periode tertentu. Dalam laporan laba rugi ini tergambar jumlah pendapatan dan sumber-sumber pendapatan yang diperoleh. Kemudian juga tergambar jumlah biaya dan jenis-jenis yang dikeluarkan selama periode tertentu.

3. Laporan Perubahan Modal

laporan yang berisi jumlah dan jenis modal yang dimiliki pada saat ini. Kemudian, laporan ini juga menjelaskan perubahan modal dan sebab-sebab terjadinya perubahan modal di perusahaan.

4. Laporan Arus Kas

laporan yang menunjukkan arus kas masuk dan kas keluar di perusahaan. Arus kas masuk berupa pendapatan atau pinjaman dari pihak lain, sedangkan arus kas keluar merupakan biaya-biaya yang telah dikeluarkan perusahaan.

5. Laporan Catatan Atas Laporan Keuangan

Laporan ini memberikan infomasi tentang penjelasan yang dianggap perlu atas laporan keuangan yang ada sehingga menjadi jelas sebab penyebabnya.

Analisis rasio adalah merupakan kegiatan membandingkan angka-angka yang ada dalam laporan keuangan dengan cara membagi satu angka dengan angka lainnya . Jenisjenis rasio keuangan yang digunakan dalam penelitian ini, yaitu:

1. Current Ratio. Rasio untuk mengukur kemampuan perusahaan dalam membayar kewajiban jangka pendek atau utang yang segera jatuh tempo pada saat ditagih secara keseluruhan.

2. Debt to Assets Ratio. Rasio utang yag digunakan untuk mengukur berapa besar aktiva perusahaan dibiayai oleh utang atau seberapa besar utang perusahaan berpengaruh terhadap pengelolaan aktiva.

3. Debt to Equity Ratio. Rasio yang digunakan untuk menilai utang dengan ekuitas. Rasio ini digunakan untuk mengetahui jumlah dana yang disediakan peminjam (kreditor) dengan pemilik perusahaan.dengan kata lain rasio ini untuk mengetahui setiap rupiah modal 
sendiri yang dijadikan untuk jaminan sendiri merupakan rasio untuk mengukur laba bersih sesudah pajak dengan modal sendiri. Rasio ini menunjukkan efisiensi penggunaan modal sendiri.

4. Margin Laba Bersih (Net Profit Margin). Ukuran keuntungan dengan membandingkan antara laba setelah bunga dan pajak dibandingkan dengan penjualan. Rasio ini menunjukkan pendapatan bersih perusahaan atas penjualan.

5. Hasil Pengembalian Ekuitas (Return On Equity). Hasil pengembalian ekuitas (Return On Equity/ROE) atau rentabilitas modal

Menurut (Hery \& Si, 2015), analisis trend merupakan teknik analisis yang digunakan untuk mengetahui toleransi keadaan keuangan dan kinerja perusahaan, apakah menunjukkan kenaikan atau penurunan. Menurut (Harahap, 2007) analisis trend bertujuan untuk mengetahui tendensi atau kecenderungan keadaan keuangan suatu perusahaan di masa yang akan datang kecenderungan naik turun maupun tetap. Analisis ini dimaksudkan untuk mengetahui perkembangan koperasi melalui rentang perjalanan waktu yang sudah lalu dan memproyeksi situasi masa itu ke masa yang berikutnya. Menurut (Algifari, 2013), permasalahan utama dalam membuat ramalan menggunakan persamaan trend sekuler adalah mencari persamaan trend yang paling bai (best fitting) untuk membuat ramalan. Metode yang sering digunakan untuk menentukan persamaan trend yang terbaik dalam analisis deret berkala adalah metode kuadrat terkecil (least square method). Dengan menggunakan metode ini, persamaan trend yang diperoleh merupakan persamaan trend yang paling baik untuk membuat ramalan. Karena persamaan tersebut akan menghasilkan ramalan dengan kesalahan kuadrat paling kecil (least square error).

Analisis common size adalah teknis analisis yang menggunakan penyederhanaan angka-angka yang terdapat dalam laporan keuangan. Proses ini memerlukan angka dasar yang ditetapkan sebagai dasar perhitungan angka konversi. Analisis common size dilakukan untuk melihat struktur keuangan baik dari daftar neraca, laba/rugi, atau arus kas. Untuk melihat struktur keuangan ini maka laporan keuangan dikonversikan ke bentuk persentase dengan mengaitkan dengan pos penting. Pos penting itu misalnya penjualan untuk laba/rugi, pos total aktiva untuk neraca. Menurut (Wartoyo, 2013) dalam praktiknya analisis common size disusun dengan menghitung tiap-tiap rekening dalam laporan laba rugi dan neraca menjadi proporsi dari total penjualan (untuk laporan laba rugi) atau dari total aktiva (untuk neraca).

Dari analisa trend common Size ini, menunjukan perkembangan persentase kenaikan dan penurunan dari setiap komponen selama tiga periode terakhir. Dengan sistem Koperasi Simpan Pinjam yang kegiatanya mencakup menghimpun dan menyalurkan dana anggota. Dengan presentase pada piutang lebih besar dari pada komponen lainnya yang menandakan alur kas yang stabil dan tidak mengendap pada kas maupun bank. Sehingga koperasi dinyatakan sehat atas dasar perputaran modal dari dana simpanan pokok, simpanan wajib dan simpanan (titipan) manasuka anggota dengan penyaluran pada piutang anggota (Ratnasari, Rani (2020). Berdasarkan hasil penelitian yang telah dilakukan Vianna Okta (2016) bahwa hasil penelitian menunjukkan bahwa secara umum Koperasi Wanita Kartini Praya Dan Koperasi Wanita Kiblat Praya memiliki kinerja keuangan yang sama jika ditinjau dari analisis rasio, trend dan common size. Selanjutnya hasil penelitian yang telah dilakukan Diah Putu Julianan Dewi (2017), Hasil penelitian menunjukkan predikat tingkat kinerja kesehatan KSP 
Guna Prima Dana selama 4 tahun secara berturut-turut diperoleh jumlah skor sebesar 59,89 ; 60,1 ; 56,1 dan 58,1 dengan rerata skor sebesar 58,53 dan berada pada kategori dalam pengawasan. Analisis trend KSP Guna Prima Dana mengalami tiga kecenderungan yaitu trend naik, trend turun dan trend tetap. Analisis common size neraca dan SHU menunjukkan kenaikan dan penurunan pada tiap pos. Selanjutnya hasil penelitian yang telah dilakukan oleh Suindyah Sayekti Dwiningwarni (2019) sebagai berikut :

Hasil penelitian menunjukkan bahwa 1) Dari hasil perhitungan analisis rasio yang digunakan, maka ketiga analisis rasio, yaitu Likuiditas, Profitabilitas, Solvabilitas dan Aktifitas menunjukkan suatu kondisi yang kurang baik. 2) Dari analisis Trend menunjukkan bahwa trend cenderung mengalami fluktuasi naik atau turun. 3) Dari analisis Common Size menunjukkan bahwa pos-pos aktiva, kewajiban dan modal memberikan angka kurang sebanding atau dapat dikatakan tidak sehat, karena jumlah kewajiban lebih besar dari asset dan modal. Ini berarti dapat disimpulkan bahwa kondisi keuangan Koperasi kurang sehat, sehingga perlu adanya perbaikan pengelolaan atau manajemen. Perbaikan pengelolaan tidak hanya dari sisi keuangan tetapi juga dari sisi SDM. Salah satu penyebab kinerja keuangan koperasi kurang sehat adalah dari rasio likuiditas, solvabilitas, profitabilitas dan aktifitas menunjukkan hasil yang Kurang Baik dan Tidak Baik.

Selanjutnya penelitian yang telah dilakukan oleh Billy dkk (2018) menyatakan bahwa, Kinerja keuangan pada PT. Asuransi Jiwasraya setelah dilakukan analisis common size dapat dikatakan cukup karena data-data neraca yang mengalami kenaikan ada 13 sedangkan isi laporan laba rugi berdasarkan analisis common size diketahui 26 pos. Perusahaan PT. Asuransi Jiwasraya periode 2014 dan 2015 dinyatakan cukup baik. Selanjutnya menurut Restianti Tya, dkk (2018) menyatakan bahwa,

These results indicate that earnings before interest tax to total assets and return on equity have an impact on financial distress. While the current ratio, the retained earnings to total assets, debt to assets ratio, and total assets turnover has no influence on the financial company's distress. The conclusion of this research is that the company's financial distress condition can be avoided by reducing the financing coming from debt. In addition, increasing sales and maximizing the use of assets and equities that companies have can also reduce and avoid the company from financial distress

Laporan keuangan dalam persentase per komponen (common size statement) menyatakan masing-masing posnya dalam satuan persen atas dasar total kelompoknya, cara penyusunan laporan keuangan ini disebut teknik analisis common size dan termasuk metode analisis vertical. Penelitian ini bertujuan untuk mengetahui kondisi dan perkembangan keuangan KPRI Hikmah tahun 2017 - 2019 dengan menggunakan rasio likuiditas, solvabilitas, rentabilitas dan aktivitas, menganalisis dengan menggunakan trend dan common size.

\section{Metode Penelitian}

Objek penelitian adalah Neraca dan Sisa Hasil Usaha (SHU) pada laporan keuangan KPRI Hikmah tahun 2017 - 2019. Jenis Data: Data kualitatif adalah data yang diperoleh 
melalui wawancara terhadap berbagai pihak antara lain pihak-pihak yang terkait di bagian keuangan dan pihak-pihak yang ada pada kepengurusan koperasi. Data kuantitatif adalah data yang diperoleh melalui laporan keuangan koperasi. Sumber Data: Data primer merupakan sumber data yang diperoleh secara langsung dari sumber asli atau pihak pertama. Data primer ini yaitu berupa wawancara dengan bagian keuangan koperasi. Data sekunder merupakan data yang diperoleh peneliti secara tidak langsung melalui media perantara. Data sekunder ini yaitu berupa bukti, catatan, atau lapran historis yang tersusun dala arsip, dokumen resmi dan gambaran umum koperasi, dalam hal ini, data sekunder yang diambil dari laporan keuangan koperasi KPRI hikmah tahun 2017 - 2019. Teknik Analisis Data. Menghitung rasio likuiditas (Rasio Lancar / Current Ratio). Menghitung rasio solvabilitas ( rasio antara utang dengan modal sendiri (total debt to equity ratio) dan rasio antara utang dengan aktiva (total debt to total assets ratio). Menghitung rasio rentabilitas ( margin laba bersih (net profit margin), hasil pengembalian atas asset (return on assets), rentabilitas modal sendiri). Menghitung rasio aktivitas ( perputaran aktiva).

\section{Hasil dan Pembahasan}

Data yang dianalisis adalah data laporan keuangan koperasi KPRI Hikmah yang terdiri dari laporan keuangan neraca dan Sisa Hasil Usaha (SHU). Untuk menilai kinerja keuangan koprasi KPRI Hikmah ada beberapa teknik analisis data yang digunakan yaitu analisis rasio keuangan, analisis trend dan analisis common size.

a. Analisis Rasio Keuangan koperasi KPRI Hikmah berdasarkan rasio likuiditas, solvabilitas, rentabilitas dan aktivitas pada tahun 2017-2019 menyimpulkan bahwa rasio likuiditas berdasarkan current ratio pada tahun 2017 - 2019 termasuk dalam kriteria sangat baik karena memiliki nilai persentase yang interval rasionya 200\% sampai 250\% sehingga setiap tahunnya KPRI Hikmah mampu membayar kewajiban jangka pendeknya. Berdasarkan total debt to equity ratio termasuk dalam kriteria baik karena memiliki nilai persentase yang interbal rasionya sebesar $>20 \%-100 \%$. Berdasarkan total debt to total assets daam kriteria baik sebesar $>40 \%-50 \%$. Berdasarkan rentabilitas net profit margin termasuk kriteria sangat baik karena memiliki nilai persentase yang interval rasionya sebesar $>15 \%$. Berdasarkan return on assets termasuk dalam kriteria cukup baik karena memiliki nilai persentase yang interval rasionya sebesar $3 \%-<7 \%$. Rasio aktivitas berdasarkan perhitungan perputaran aktiva termasuk dalam kriteria tidak baik karena memiliki nilai persentase yang interval rasionya sebesar $<1$ kali. Berikut tabel perputara aktiva KPRI Hikmah tahun 2017 sampai tahun 2019 sebagai berikut.

Tabel Perhitungan Perputaran aktiva KPRI Hikmah Tahun 2017 - 2019 (dalam rupiah)

\begin{tabular}{|c|c|c|c|}
\hline Tahun & $\mathbf{2 0 1 7}$ & $\mathbf{2 0 1 8}$ & $\mathbf{2 0 1 9}$ \\
\hline Penjualan & 558.698 .811 & 631.103 .233 & 662.669 .780 \\
\hline Total Aktiva & 3.091 .865 .364 & 3.321 .080 .588 & 3.376 .033 .712 \\
\hline Perputaran Aktiva & 0.18 kali & 0.19 kali & 0.20 kali \\
\hline Naik / Turun & Turun 0.03 kali & Naik 0.01 kali & Naik 0.01 kali \\
\hline Interval Ratio & $<1$ kali & $<1$ kali & $<1$ kali \\
\hline
\end{tabular}




\begin{tabular}{|l|l|l|l|}
\hline Kriteria & Tidak Baik & Tidak Baik & Tidak Baik \\
\hline
\end{tabular}

b. Analisis Trend. Analisis trend merupakan perubahan dari nilai variabel yang relative mengalami perubahan dari waktu ke waktu. Analisis trend yang digunakan yaitu analisis trend kuadrat terkecil guna untuk menilai perkembangan koperasi KPRI Hikmah tahun 2017 sampai tahun 2019.

1. Current Ratio $\mathrm{Y}=219,49+3,21 \mathrm{x}$

2. Total debt to equity ratio $Y=90,73-2,60 x$

3. Total debt to total assets $Y=47,45-0,79 x$

4. Net profit margin $Y=16,86+0,58 x$

5. Return on assets $Y=3,41-0,06 x$

6. Rentabilitas modal sendiri $\mathrm{Y}=6,50-0,21 \mathrm{x}$

7. Perputaran aktiva $\mathrm{Y}=0,20-0,01 \mathrm{x}$

c. Analisis Common Size. Analisis common size pada sisa hasil usaha dengan perhitungan persentase dilakukan dengan cara membandingkan seluruh pos-pos pada laporan sisa hasil usaha terhadap pos pendapatan. Berdasarkan laporan Common Size atas SHU di KPRI Hikmah terdiri dari tiga pos yaitu pendapatan, biaya-biaya dan penghasilan di luar. Pada pos pendapatan saat diperbandingkan dengan total pendapatan yang memberikan kontribusi terbesar yaitu bunga. Secara signifikan tingkat bunga pada pendapatan megalami kenaikan di tahun 2017 yaitu menjadi 85,05\% namun di tahun 2018 mengalami penurunan menjadi 82,39\% dan mengalami peningkatan di tahun 2019 menjadi 83,46\%. Kenaikan atau penurunan persentase pada bunga ini tergantung dari pinjaman anggota. Pada pos biaya saat diperbandingkan dengan total pendapatan yang merupakan kontribusi terbesar adalah jasa simpanan anggota. Dimana jasa nggota ini salah satu yang dapat mensejahterakan anggota karena sebagai tambahan simpanan anggota. Tahun 2017 persentase jasa simpanan anggota mengalami kenaikan menjadi 33,41\%, tahun 2018 mengalami penurunan menjadi 30,44\% dan tahun 2019 mengalami kenaikan kembali menjadi 31,25\%. Bagi koperasi kenaikan persentase ini sebagai penambahan biaya sehingga mengurangi SHU koperasi namun semakin tinggi persentasenya dapat mensejahterakan anggota koperasi. Pada pos penghasilan di luar terdiri dari PKP-Ri dan Bank. Pada tahun 2017 mengalami kenaikan menjadi 0,88 namun di tahun 2018 mengalami penurunan menjadi 0,66 dan di tahun 2019 mengalami kenaikan kembali menjadi 0,68. Kenaikan atau penurunan pos PKP-RI ini dipengaruhi olh investasi koperasi terhadap PKP-RI. Apabila investasinya tinggi penghasilan yang didapat semakin banyak dan apabila investasinya rendah maka penghasilan yang didapat juga rendah.

d. Analisis common size pada neraca, berdasarkan pos yang ada di neraca yang memiliki pengaruh besar yaitu aktiva lancer. Pos aktiva lancar saat diperbandingkan dengan total aktiva yang memberikan kontribusi terbesar yaitu piutang anggota. Piutang anggota secara signifikan mengalami kenaikan dari tahun 2017-2019 sebesar 85,12\% .

\section{Kesimpulan}

Berdasarkan hasil analisis data keuangan koperasi KPRI Hikmah diperoleh kesimpulan bahwa tingkat likuiditas yang diukur menggunakan current ratio pada tahun 2017 - 2019 
dikategorikan sangat baik. Tingkat solvabilitas yang diukur menggunakan total debt to equity dan total debt to total assets ratio pada tahun 2017 - 2019 dikategorikan baik. Tingkat rentabilitas diukur menggunakan net profit margin pada tahun 2017 - 2019 dikategorikan sangat baik. Return on assets dan rentabilitas modal sendiri dikategorikan cukup baik. Tingkat aktivitas yang diukur menggunakan perputaran aktiva dikategorikan baik. Hasil analisis trend pada current ratio, total debt to equity ratio, total debt to total asset ratio dan net profit margin pada tahun 2017 - 2019 mengalami peningkatan kinerja, sedangkan return on assets, rentabilitas modal sendiri dan perputaran aktiva mengalami penurunan. Hasil analisis common size pada laporan neraca dan sisa hasil usaha cenderung mengalami penurunan dalam perkembangan keuangannya. Peneliti menyarankan yaitu : rasio likuiditas memiliki kondisi dan perkembangan keuangan yang sangat baik sehingga koperasi perlu mempertahankan dan meningkatkan total aktivanya. Rasio solvabilitas yang dilihat dari total debt to equity rasio dan total debt to assets masih perlu dilakukan pengurangan utang usaha agar tidak melebihi total aktiva dan modal sendiri dan perlu meningkatkan usaha koperasi supaya di tahun berikutnya bisa semakin baik lagi. 


\section{Bibliografi}

Algifari. (2013). Statistika Deskripsi Plus Untuk Ekonomu Dan Bisnis. UPP STIM YKPN.

Billy dkk. (2018). Analisis Common Size Statement Pada PT. Asuransi Jiwasraya (Persero) Cabang Manado Kota. Jurnal Administrasi Bisnis. FISIP. Universitas Sam Ratulangi.

Diah Putu Juliana Dewi (2017). Analisis Pengukuran Kinerja Koperasi Berdasarkan Peraturan Deputi BIdang Pengawasan Kementrian Koperasi Dan Usaha Kecil Dan Menengah Republik Indonesia Nomor 06/PER/DEP.6/IV/2016, Analisis Trend Dan Common Size Pada KSP Guna Prima Dana Kuta Selatan - Kabupaten Bandung Tahun 2012 - 2015. Jurusan Akuntansi . Universitas Pendidikan Ganesha. Singaraja.

Fahmi, I. (2013). Analisis Laporan Keuangan. Alfabeta.

Harahap, S. S. (2007). Analisis Laporan Keuangan. PT. Raja Grafindo Persada.

Hery, H., \& Si, M. (2015). Analisis Laporan Keuangan Pendekatan Rasio Keuangan. Jakarta: Buku Seru.

Ikatan Akuntan Indonesia. (2009). Pernyataan standar akuntansi keuangan. Jakarta: Salemba Empat.

Kasmir. (2012). Bank dan Lembaga Keuangan Lainnya (Edisi Revsi). Raja Grafindo Persada.

Mawardi, W. (2004). Analisis Faktor Faktor Yang Mempengaruhi Kinerja Keuangan Bank Umum Di Indonesia (Studi Kasus Pada Bank Umum dengan Total Asset Kurang Dari 1 Trilyun). Program Pascasarjana Universitas Diponegoro.

Ratnasari, Rani (2020). Analisa Laporan Keuangan Dengan Menggunakan Metode Trend Common Size Periode Tahun 2017-2019 Pada Koperasi Simpan Pinjam Simpenan Pameungkeut Banda Kota Tasikmalaya. Universitas Siliwangi.

Restianti Tya dkk. (2018). The Effect Of Financial Distress Conditions In Sub Industrial Sector Company. AAJ. Accounting Analysis Journal.

Suindyah Sayekti Dwiningwarni (2019). Analisis Rasio Keuangan Untuk Mengukur Kinerja Keuangan Koperasi Serba Usaha. JMACC. Universitas Darul Ulum Jombang.

Toto, P. (2011). Analisis laporan keuangan teori dan aplikasi. Jakarta: PP.

Vianna Okta (2016). Analisis Perbandingan Kinerja Keuangan (Studi Kasus Pada Koperasi Wanita Kartini Praya Dan Koperasi Wanita Kiblat Praya Periode 2010 - 2014). Jurnal Distribusi. Jurnal Ilmu Manajemen Dan Bisnis. FEB. Universitas Mataram.

Wartoyo. (2013). Analisis Common Size terhadap Kinerja keuangan Bank Syariah. Jurnal. IAIN Cirebon. 